\title{
A Study on the Comparative Analysis of Hausa and Jar Pronouns of Northern, Nigeria
}

\author{
Furera Adamu Garba \\ Department of Nigerian Languages and Linguistics, Bauchi State University, Gadau, Nigeria
}

\section{Email address:}

Fureragarba@gmail.com

\section{To cite this article:}

Furera Adamu Garba. A Study on the Comparative Analysis of Hausa and Jar Pronouns of Northern, Nigeria. International Journal of Language and Linguistics. Vol. 9, No. 3, 2021, pp. 100-105. doi: 10.11648/j.ij11.20210903.16

Received: April 30, 2021; Accepted: May 15, 2021; Published: May 27, 2021

\begin{abstract}
This paper title "A Comparative Analysis of the Hausa and Jar Pronouns", started with brief introduction of importance of language in human endeavor, meaning of pronoun. The historical background of both languages was reviewed, and also the work examines the behavior of the Hausa and Igbo Pronouns. As such, the work analytically compares the nature and positions of pronouns within the sentences or noun phrase of the two languages (Hausa and Igbo). However, this paper identifies the similarities and differences of both singulars and plural Pronouns, such as the Hausa language, has gender in second person and third person, Singular Pronouns Kai, Shi, and Ita. While Jar languages has no gender in second and third person pronouns. Also where English and Jar languages have shared the same rules in second person and object pronouns (you) while the rule differs with Hausa. Another difference is the positions of some subject pronouns singular in Jar languages almost always come after an action word or verb in a sentence, while in Hausa almost always the singular personal subject pronouns appear before an action word (Verb), and methodology of research has been discussed in the paper.
\end{abstract}

Keywords: Comparative Analysis, Pronouns, Languages, Hausa, Jar

\section{Introduction}

Language is the most important tool for communication and is the most tasking area of human endeavor. The human languages are distinct from other means of communication. Hausa language belongs to the Chadic group of the AfroAsiatic language family and is the native language of the states in the southern part of Niger Republic and Northern part of Nigeria. There are sizable population of Hausa speakers in Borno, Jos Plateau, Adamawa, Nassarawa, Benue, Ibadan, Lagos Ondo and Niger. However, since language is said to be inherently variable, there are many varieties of Hausa language, but the Variety of the Hausa the researcher would use in the course of this paper is the standard.

Jar is a Bantoid language, which belongs to the NigerCongo language family, and is being spoken natively in Bauchi, Dass, Tafawa Balewa, Bogoro and Alkaleri local government areas of Bauchi state. They are also found in Kanam and Kanke Local governments of Plateau State, The Mbula people of Adamawa State and Mama people in Mama local government of Narawa State, and the Bille people of
Cross-river State also speak a variety of Jar.

This paper "A Comparative Analysis of Hausa and Jar pronouns", examined the categorical differences and similarities of Pronouns through comparison. Moreover, a pronoun is a universal phenomenon across languages, and it can be used as replacement or substitution for nouns or noun phrases [4].

As we said earlier, since language is said to be inherently variable, and indeed the pronouns take different forms and perform various Functions in different languages of the world, and likewise through comparison, the paper tried to investigate the existence of such differences between Hausa and Jar pronouns to see if there is any.

\section{Literature Review}

Many scholars have defined pronoun as one of the grammatical concepts; the earliest attempt was made by [11] who states that, pronouns have been defined as "a traditional part of speech that is typically used as a substitute for a noun or noun phrase" [2] said pronouns serve as substitutes for noun phrase and they can be found where noun normally 
feature. Pronouns make specific reference to people and things. Thus, pronouns are words that take the place of one or more nouns.

However, pronouns can do all the things that noun can do. They can be subjects, indirect objects, object of preposition and more.

Newman [7] argues that pronouns in Hausa can be broadly classified into two main types (i) personal pronouns, and (ii) non personal pronouns.

According to him, the former are marked for person, number, and in the singular only-gender, and the latter may be marked for number and gender, but not for person like nouns they are inherently third person.

Wurma [9] Said "A Pronoun is one of the non-adverbial items that comes under the noun phrase."

\subsection{Type of Pronouns in Hausa}

According to Scholars, there were seven types of pronouns in Hausa language.

They are as follows:

Personal pronouns (Wakilin Suna Ambatau)

Demonstrative pronouns (Wakilin Suna Nunau)

Indefinite pronouns (Wakilin Suna Kaikaitau)

Reflexive pronouns (Wakilin Suna Mayau/Komau)

Possessive pronouns (Wakilin Suna Mallakau)

Interrogative pronouns (Wakilin SunaTambayau)

Relative pronouns (Wakilin Suna Dogarau)

\subsection{The Personal Pronouns in Hausa}

(Walikin Suna Ambatau); According to Zarruq [10] this is a type of pronoun. Some scholars like Ayanwum [2] and Newman [7] called it independent because it can stand alone in a sentence.

Besides that, this type of Pronoun can be marked in terms of number or gender, and also it can be Marked or classified in terms of first person, second person speaking to and third person spoken about. Eg:

$\begin{array}{lllllll} & \text { M } & & \text { f } & & \text { Pl. } & \text { 'we' } \\ 1^{\text {st }} & \text { Ní } & \text { 'I' } & \text { ní } & \text { 'I } & \text { mû } & \\ 2^{\text {nd }} & \text { Káì (pl) } & \text { you (m) } & \text { Ké } & \text { you (f) } & \text { Kû } & \text { You } \\ 3^{\text {rd }} & \text { Shí } & \text { 'he' } & \text { itâ } & \text { 'she' } & \text { sû } & \text { They }\end{array}$

\subsection{Weak Direct Object Pronoun}

$\begin{array}{lllllll} & \text { M } & & \mathrm{f} & & \text { Pl. } & \text { 'we' } \\ 1^{\text {st }} & \text { Ní } & (\mathrm{me}) & \text { ní } & \text { me } & \text { mú } & \text { 'us' } \\ 2^{\text {nd }} & \text { Ká } & \text { you (m) } & \text { kí } & \text { you (f) } & \text { kú } & \text { 'you' (Pl) } \\ 3^{\text {rd }} & \text { Shí 'him' } & \text { tá } & \text { 'her' } & \text { sú } & \text { 'them' }\end{array}$

Demonstrative Pronoun (Wakilin Suna Nunau), are words which serve to locate an entity in space in terms of whether it is near to or away from the speaker. eg; this (Wannan) near singular (m), that, (wancan/waccan) far and singular, (f) these (waxannan) near and plural, and those (waxancan) Indefinite Pronoun (Wakilin Suna Kai-kaitau)

Galadanci [6] Said; this type of Pronouns (Indefinite Pronouns) in Hausa, it can be classified based on number and gender grammatically. And also it's almost always used it while irony. eg.

\begin{tabular}{|c|c|}
\hline $\begin{array}{l}\text { Wánè (m) Singular, } \\
\text { Wáncè (f) Singular, } \\
\text { Sú wánè (m/f) Plural } \\
\text { Sú wáncè (f) Plural }\end{array}$ & $\begin{array}{l}\text { Somec } \\
\text { Somee } \\
\text { Some } \\
\text { Some }\end{array}$ \\
\hline \multicolumn{2}{|c|}{ Possessive Pronouns: (Wakilin Suna } \\
\hline my/mine & Náwà \\
\hline yours $(\mathrm{Sg})$ 'm' & Nák \\
\hline yours (Sg) 'f' & Nák \\
\hline yours $(\mathrm{Pl})$ & Náḱù \\
\hline their/theirs $(\mathrm{Pl})$ & Nás $\underline{s}$ \\
\hline
\end{tabular}

Interrogative Pronouns. In Hausa language, interrogative Pronouns are normally used to ask question. These include: me (What), Wa (Who), Su wa? (Who, pl), Wanne (Sg) 'M', (Who), wacce (Sg) 'f' (Who), and wadanne (Pl), whose or that, which $(\mathrm{Sg})$ wanne.

Relative Pronouns in Hausa: (Wakilin Suna Dogarau). Relative Pronoun introduces embedded classes, which usually function as a single modifier for the noun phrase. Anyanwu [2] and it can be classified in terms number and gender. Eg.

$\begin{array}{lll}\text { Who } & (\mathrm{Sg}) \text { 'm' } & \text { wanda Tilo }(\mathrm{Nj}) \\ \text { Whom } & (\mathrm{Sg}) \text { 'm'/'f' } & \text { wandà ko wadda tilo }(\mathrm{Nj} \text { da } \mathrm{Mc}) \\ \text { Whose } & (\mathrm{Pl}) & \text { waxandà }(\mathrm{jm})\end{array}$

Hausa language has proverbial Pronouns (Wakilin Suna Zagin Aikatau).

This type of Pronouns it's always came immediately before verb in a sentence, $\mathrm{Eg}$.

$\begin{array}{llll}\text { Ya } & (\mathrm{Sg}) \text { ' } \mathrm{m} \text { ' } & \text { he } & (\mathrm{Sg}) \text { ' } \mathrm{m} \text { ' } \\ \text { Ta } & (\mathrm{Sg}) \text { 'f' } & \text { she } & (\mathrm{Sg}) \text { 'f' } \\ \text { Sun } & (\mathrm{Pl}) \text { 'm' } & \text { they } & (\mathrm{Pl})\end{array}$

\subsection{Pronouns in Jar}

The Jar Pronouns are in a way similar to that of the Hausa and are divided into the following categories:

\subsection{Personal Pronouns in Jar}

Just like in Hausa, the personal pronoun in Jar can pronoun. Some scholars it is independent because it can stand alone in a sentence.

But one big difference with that of Hausa is this type of Pronoun can be marked in terms of number but not gender, and also it can be Marked or classified in terms of first person, second person speaking to and third person spoken about.

These type of pronoun falls into three types or forms eg:

Subject Possessive pronoun in Jar:

Singular

$\begin{array}{ll}1^{\text {st }} & \mathrm{Mi} \\ 2^{\text {nd }} & \mathrm{Wu} \\ 3^{\text {rd }} & \mathrm{Yi}\end{array}$


Plural

$\begin{array}{ll}1^{\text {st }} & \text { Su } \\ 2^{\text {nd }} & \text { Wun } \\ 3^{\text {rd }} & \text { Ya }\end{array}$

In Jar language the $1^{\text {st }}$ person singular pronoun is not included in certain sentences describing events in the past. E.g In this sentence, E.g lim garmalin - I ate food.

Object Possessive pronoun in Jar:

These type of pronouns are used to indicate possession in a sentence

(c) Possessive forms

\subsection{Demonstrative Pronoun in Jar}

These are pronouns, which serve to locate an entity in space in terms of whether it is near to or away from the speaker. eg; Mi (this) near singular, Ma, (that) far and singular, bi (these) near and plural, and ba (those)

\subsection{Possessive Pronouns}

This type of pronoun shows possession and just like the other Gera pronouns it does not show Gender.

Eg. i- Lam (mine), lu (yours, Sg), li (his) lawun (yours, $\mathrm{Pl}$ ), lasu (ours), li (his/hers), le (their/theirs pl.)

Interrogative Pronouns. Just like in Hausa, In Jar language, interrogative Pronouns are normally used to ask question. Examples are: man (What), yan (Who, Sg), bi yan (who, pl), make (which), li yan (whose).

Relative Pronouns in Jar: this type of pronoun introduces embedded classes, which usually function as a single modifier for the noun phrase, and just like the other Jar pronouns, it can only be classified in terms number and not gender. E.g:

Sg.

Maa (Whom)

Plural

baa (whose)

This type of pronoun fall into three types or forms eg.

(a) Subject forms

(b) Object form

(c) Possessive forms

The Jar personal Pronouns are divided into independent (emphatic) and dependent (Non-emphatic) forms.

Jar Pronouns are also divided into the following categories:

(a) Personal Pronouns (Nnochionwe)

(b) Impersonal Pronouns (Nnochimpesin)

Qkafo [8] categorize Ibgo pronounce into seven categories, he added Possessive pronoun.

Anyanwu [2] and Emenanjo [5] categorized the Igbo

Pronouns into the following:-

i. Independent Pronouns

ii. Dependent Pronouns

iii. Impersonal Pronouns

iv. Reflexive Pronouns

v. Relative Pronouns vi. Interrogative Pronouns

vii. possessive Pronoun

Independent Pronouns (Emphatic) forms. Eg.

$\begin{array}{ll}\text { Independent } & \begin{array}{l}\text { Dependent } \\ 2^{\text {nd }} \mathrm{i} / \mathrm{i}(\mathrm{Sg}) \text { 'm'/'f' }\end{array} \\ \text { Mù } / \mathrm{m} \text { 'I' }(\mathrm{Sg}) & 3^{\text {rd }} \mathrm{o} / \mathrm{o}(\mathrm{Sg}) \text { 'm'/'f' } \\ \text { yá ( } 3 \mathrm{Sg}) \text { 'm' 'm'/'f' } & \\ \text { anyì 'We' } & \\ \text { Unù }(\mathrm{Pl}) \text { you } & \\ \text { há }(\mathrm{Pl}) \text { they } & \end{array}$

Anyawu [2]. Said "impersonal Pronouns in Igbo refer as indefinite Pronouns, has no definite referent. It is represented by the non-close front vowel e./a (Subject to vowel harmony). The use of this Pronouns in sentences is shown below, the impersonal Pronouns functions more like the unagented passive. Eg:

É Sìrì Nrì Food was cooked (by someone)

\section{Reflexive Pronoun}

Emenanjo [5] also called it exclusive; the exclusive may also be expressed with the phrase 'onwe $\mathrm{X}$ ' where $\mathrm{X}$ is the number used after the independent forms thus: Anyawun [2] Said "Reflexive Pronoun is a type of Pronouns refers back to an already mention entity particularly in the same close matching the referent in number and person.

Reflexive Pronoun in Igbo are coded in 'onwe' i- Pronoun: 'onwe' m, 'myself': onwegi yourself,: 'onwe' ya, 'himself'/herself,: 'onwe' anyi 'ourselves': 'onwe' unu yourself) (Pl): 'onwe' ha themselves?. But Emenanjo give an example as:

$\begin{array}{lll}\text { Mmù: } & \text { ònwé M } & \text { 'I myself' } \\ \text { Ngi: } & \text { ònwé g! } & \text { 'You }(\mathrm{Sg}) \text { 'm'/'f' Yourself' } \\ \text { Yá: } & \text { ònwé ya } & \text { 'He/her himself/herself }(\mathrm{Sg}) \\ \text { Anyi: } & \text { ònwé anyì } & \text { 'We our selves' } \\ \text { Unu } & \text { ònwé unù } & \text { You }(\mathrm{N}) \text { Yourselves } \\ \mathrm{Ha} & \text { ònwé ha } & \text { They themselves. }\end{array}$

\section{Relative Pronoun}

Anyawu [2] Said "Reflexive Pronouns in Igbo are 'onye' 'who' 'M'/'F' and nke' that.

\section{Interrogative Pronouns in Igbo}

Interrogative Pronouns in Igbo are normally used to ask questions and they are more prominent in the dialect. Those include

Nke olee "which" gini "What" mgbe "When? onye 'Who'? kedu/olee 'Who' ebe olee' 'Where'?

But Emenanjo [5] used it as Interrogatives, he said, "The Interrogatives belong in a closed class. eg. Anaa "How?" chumo 'Which?' 'Who?". Ebee' 'Where?' Gini 'What?' Kedu "how?" Onye 'who', and. Although, Ebere [4]. Said it is 
also possible to use kedu to ask almost all the questions in Igbo.

\section{Theoretical framework}

Theoretical frame work on which this work adopted is comparative theory of languages. The comparative theory is a technique for studying the development of languages by performing a feature-by-feature comparison of two or more languages that, belongs to different family of languages, in order to find out an existence differences and similarities of the languages. The comparative theory was developed over the 19th century. Key contributions were made by the Danish scholars Rasmus Rask and Karl Verner and the German scholar Jacob Grimm. The first linguist to offer reconstructed forms from a Proto-language, was Schleircher. However, Bloomfield' Fires, Harris, James, were contributed and developed the theory in the field of linguistics analysis. This present work, "Hausa and Igbo Pronouns: A comparative analysis", attempts to compared the two languages which belong to the different family of languages in order to know the differences and similarities from them.

Methodology of research

The data for this study were obtained from both primary and secondary sources. For the primary source, the native speakers from both languages (Hausa and Igbo) were interviewed for the purpose of sourcing data, while the secondary sources also used where some text books from both languages consolidated.

\section{Data Presentation and Analysis}

Comparison of Hausa and Igbo Pronouns, in terms of gender and syntactic positions in which they appear in a sentence, closed, noun phrase or verbal phrase.

The Pronouns exist in both Hausa and Igbo languages, but Hausa has seven types of Pronouns. According to Hausa Scholars, while Igbo language also has seven types of Pronouns according to some Igbo scholars, as we indicated above.

And also this work research discovered that, Igbo language is genderless in terms of Singular Pronouns e.g Second person, Singular, $\mathrm{i} / \mathrm{I}$, and gig all refers to both male and female unlike in Hausa Language. Examples:-

$$
\text { I Choro } \mathrm{m} \text { ? You }(\mathrm{Sg})
$$

refer to both male and female gender, but in Hausa the second person Pronouns should be either "Ka" or "KI" where by ka refer to male gender while ki, refers to female gender. And also an object Pronoun "gi" in Igbo language is also genderless because it's refer to both gender "You" (Sg) e.g

mmu na gi

I' and you (Sg)

refers to male or female gender, while in Hausa language an object Pronoun "You" can take either male gender Ka, or female gender Ki e.g
Na Kira ki
I called you

or

\section{Na Kira ka}

I called you

that is to say English and Igbo have shared the same rules in second person object Pronouns (you), while Hausa language differs.

However, Hausa language has a gender in third person both in subject and an object Pronouns, while in Igbo are absent ${ }^{1}$. Means it has no gender in both. Examples:-
O Jere ahia
He went to the market"
O Jere ahia
She went to the market"

In both sentences the third person subject Pronouns, have been used in both male and female gender. While in Hausa the situation is not the same because Hausa language has a gender in $3^{\text {rd }}$ person $(\mathrm{Sg}$ ) Pronouns, examples:-

Pronouns should be 'ya', as male gender and 'ta' as female 'gender' e.g

$\begin{array}{ll}\text { Ya tafi kasuwa } & \text { 'He went to the market' } \\ \text { Ta tafi kasuwa } & \text { 'She went to the market' }\end{array}$

And also in another examples of an object Pronoun 'ya' in Igbo has no gender e.g

O Kporo ya 'he / she called him/her.

While In Hausa language the present of gender is there in $3^{\text {rd }}$ person an object Pronoun, examples:-

$\begin{array}{ll}\text { Ya kira ta } & \text { 'he called her' } \\ \text { Ya kira shi } & \text { 'he called him' }\end{array}$

The Hausa and Igbo Language have first, second, and third person Plural Pronouns.

1. Even though, in Igbo language there is no gender connotation in $2^{\text {nd }}$, and $3^{\text {rd }}$ person singular pronouns, but the native speakers have their own way to understand who is refer to between male or female gender usually from asking question.

And they are similar in terms of gender, because all languages (Hausa and Igbo) shows the plurality and unique in gender in all the Pronouns from both languages. Example.

$\begin{array}{lll}\text { Anyi } & \text { means "we” } & \text { in Hausa Means 'Mu' } \\ \text { Unu } & \text { Means You (Pl) } & \text { and Ku in Hausa } \\ \text { Ha } & \text { Means They } & \text { and su in Hausa language }\end{array}$

Another similarity in the using of third person preverbal pronoun (ya) both Hausa and Igbo language are using it, e.g. Ya tafi kasuwa (He went to the market). But in Igbo language it has been used exceptionally to emphasize more especially in local dialect, e.g. yanwa (he is the one).

Moreover, the research work shows that, how the object and subject forms are used in a sentence, in Hausa and Igbo languages. In Igbo language, the personal Pronouns $1^{\text {st }}$ person speaking mu/m Play multifunction roles, whereby it can appear, as a subject Pronouns or it can appear as an object position in a sentence. e.g 
$\mathrm{nM}$ ga ejee chi

I' shall go tomorrow

The Pronoun ' $\mathrm{m}$ ' ( $\mathrm{Sg}$ ) stand as a subject Pronoun because it came at the beginning of the sentence.

$$
\text { o Juru/Mu ' he/she asked me }
$$

In the above sentence the Pronoun ' $\mathrm{m}$ ' functioned as an object Pronoun, unlike in Hausa language, where it has a subject personal Pronoun of first person speaking as $\mathrm{Na}$ which is ' $\mathrm{I}$ ', and NI as an object Pronoun which is me e.g;
$\mathrm{Na}$ dake shi
'I heat him'

At the above sentence we can see the preverbial Pronouns $\mathrm{Na}$ in the syntactic position as a subject Pronoun. But in the sentence like.

\section{Ya dake Ni}

'he beat me'

Here Ni function as an object Pronoun me.

Although in some cases we can found the personal pronoun of $1^{\text {st }}$ person $(\mathrm{Sg}) \mathrm{Ni}$ in Hausa used as a subject Pronoun, e.g.

Ni na dake ta.

'I beat her?

Nevertheless, Hausa language has a first person speaking personal Pronoun $\mathrm{Na} / \mathrm{Ni}$ as a subject Pronoun while Ni always appears as an object Pronoun in $1^{\text {st }}$ person $(\mathrm{Sg})$ speaking. And Igbo language has $\mathrm{Mu} / \mathrm{I}^{\mathrm{m}}$ ' as both an object or subject Pronoun in a sentence. In another examples.

$$
\begin{array}{ll}
\text { ejere } M ' & \text { 'I went' } \\
\text { a Zara M' } & \text { 'I swept }
\end{array}
$$

In the two sentences above we can see the position in which the Pronoun ' $M$ ' found itself immediately after verb ejere azara, unlike in Hausa language, where the subject personal Pronoun $\mathrm{Ni}$ or $\mathrm{Na}$ always came or appears before an action word or verb. Example:-

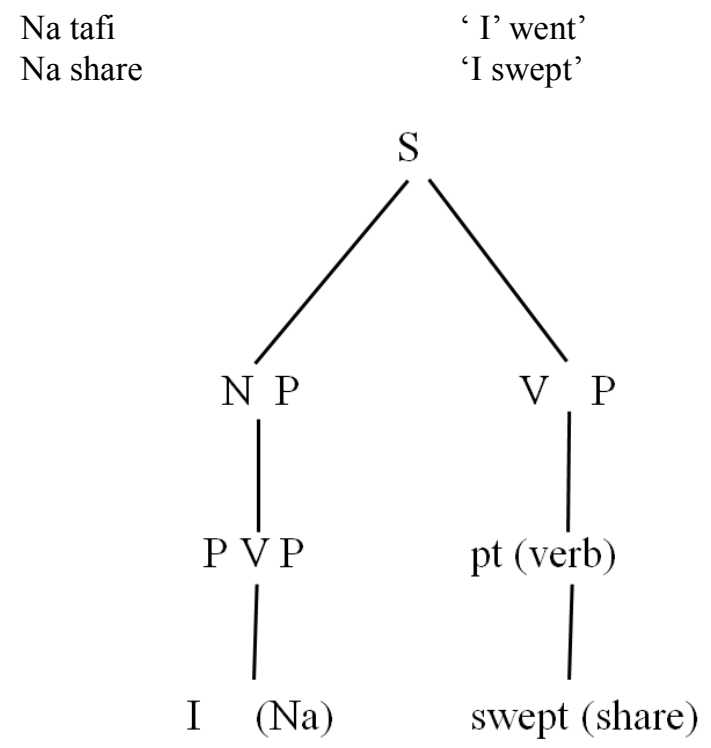

But in Igbo diagram should be

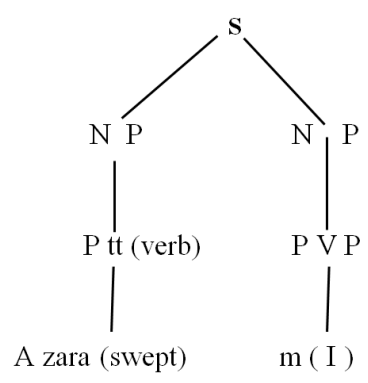

Means swept I. But contrary to Hausa syntactic constituents.

As in Emenanjo [5] gave an example of $3^{\text {rd }}$ person $(\mathrm{Pl})$ also came after a verb, e.g:
e jere
ha
(ahia)
'They went' (to the market)
a zara

ha (ihe)
'They swept.' (something)

It almost all they appears after an action word like ' $\mathrm{M}$ ' $(\mathrm{Sg})$. Diagram 2

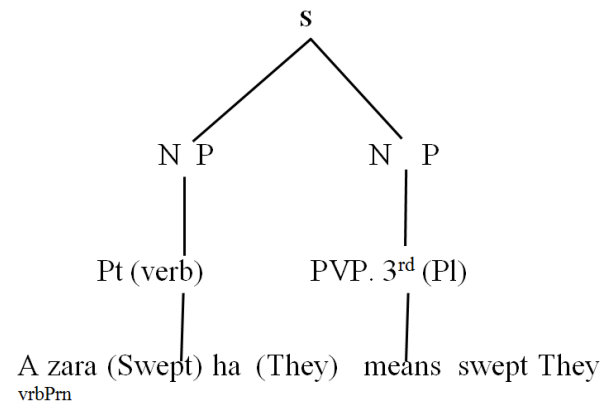

But in Hausa language, the syntax structure should be,

$$
\text { sun share }
$$

(They Swept)

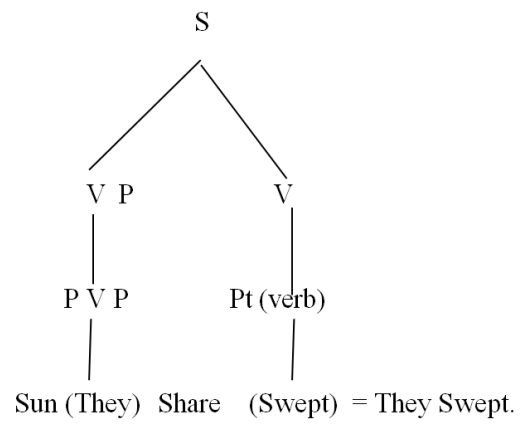

Another differences in Hausa and Igbo Pronouns are; Independent personal Pronouns for $3^{\text {rd }}$ person ' $y a$ ' and $\mathrm{O}$ which is dependent Pronoun. Independent personal Pronoun 'ya' for $3^{\text {rd }}$ person it's almost always came at the end of the sentence while $\mathrm{O}$ dependent personal Pronoun for 3rd person $(\mathrm{Sg})$ comes at the beginning of the sentence in both gender. Eg.

$$
\begin{array}{ll}
\text { I kpor 'ya' } & \text { 'you (Sg) called him/her' } \\
\text { O Jere ahia } & \text { 'he/she (Sg) went to the market }
\end{array}
$$

While in Hausa language have 'ya' or 'ta' as a subject preverbial Pronoun and 'ta' and shi appears as an object personal Pronoun for $3^{\text {rd }}$ person $(\mathrm{Sg})$.

In addition possessive pronoun in Hausa language has a 
$1^{\text {st }}$ Person plural $2^{\text {nd }}$ person singular and plural and $3^{\text {rd }}$ person singular and plural. And $1^{\text {st }}$ person singular excluded in this case and it has a feature as Noun + Pronoun e.g. Makarantata $($ my school $=$ mine) which is attached together always. And all the race mentioned above have the characteristic feature as noun + conjunction (short) + pronoun e.g. Makarantarka (your school = yours), Makarantarsu (their school $=$ theirs). While in Igbo the possessive pronoun characteristically has a feature as noun + pronoun in all forms of it is possessive pronouns as indicated above. That is to say Igbo possessive pronoun it is always separated due to the absent of short conjunction in Igbo language as in that of Hausa Language.

\section{Conclusion and Suggestion}

In this paper, attempt has been made to examine and compared pronouns in Hausa and Igbo Languages, and also classified conventional usage interns of syntactic positions and their functions. Finally, since this study is an exploratory one, it seems necessary to suggest that, more researchers are needed in order to contribute to the grammatical concept at verious levels and documented the workers to avoid language endergment or dieying.

\section{References}

[1] Awwal et al (2012). The Champion of Hausa cikin Hausa, A festschrift in Honour of Dalhatu Muhammad, Department of African Languages and Cultures, A. B. U. Zaria.

[2] Anyanwu (2010). Basic Linguistics for Nigerian languages, shebiotimo publications 72 Araromi, Street, Ijebu-ode.

[3] Abdu I. (2012) Kwatancin Rukunan Hanawun Hausa Da Angas, Kundin Digiri Na biyu, Sashen Harsuna Da Al'adun Afrika, Tsangayar Fasaha, Jami'ar Ahmadu Bello, Zariya.
[4] Ebere D. C (2016) Igbo Language, Simplified for Schools and Colleges, Success Computer and Business Venture, Kano.

[5] Emenanjo N. E (1999) Element of modern Igbo Grammar, "A Descriptive Approach" University Press Limited, Ibadan.

[6] Galadanci, M. K. M (1976): An Introduction to Hausa Grammar. Longman Nigeria L. t. d.

[7] Newman P. (2000) the Hausa Language An Encyclopedic Reference Grammar, New Haven: Yale University Press.

[8] Okafo et al., (2012): Nhazi Asusu Igbo, maka Ue inio Sekondiri Na Koleji WASSCE, NECO, JAMB. Published By A. C Global Publishing Co. (Nig) Anambra State.

[9] Wurma A. G. (2005): Daidaitacciyar Hausa da Qa'i'dodjin Rubutunta, Kaduna.

[10] Zarruq (1998) BishiyarLi'irabi a Nazarin Jumlar Hausa. Cibiyar Ilmi Jami'ar Ahmadu Bello Zariya.

[11] Kargi S. G, Hassan S, and Salisu A. B. (2019). Hausa and Igbo Pronouns: A Comparative Analysis. Conference on Literature and Governance: The African Experience. Department of English Studies, UniPort. 3-6 September.

[12] Muhammad. S (2015). Jaranci: Not Just another language. Ginja Media Limited. Www.ginjame/printshop. Bauchi.

[13] Usman A. M, Hamisu M (2013). Reading and Writing Jar: A Proposal for writing The Jar Language. Jar Language Project. Bauchi.

[14] Garba F. A. (2014). Language Endangerment In Nigeria: A Case Study of Jar Language of Bauchi State. International University of Africa, Khartoum.

[15] Garba. F. A. (2021). The Assimilation of Consonants In Bankal, A Jar Dialect.

[16] Festschrift In Honour of Professor Munkaila. Department of Languages and Linguistics. University of Maiduguri. 